\title{
The Anatomy Of EEO's Level Playing Field
}

Edward L. Powers, University of North Carolina Pembroke, USA

\begin{abstract}
The election of President Barack Obama, and the candidacies of Hillary Clinton and Sarah Palin raise the issue of whether we continue to need equal employment opportunity and/or affirmative action. The concept of a level playing field is carefully developed, and provides a basis for a more thorough analysis of the future of equal employment opportunity and affirmative action.
\end{abstract}

\section{INTRODUCTION}

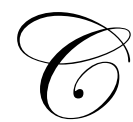

ourt decisions and new legislation have been fine-tuning America's Equal Employment Opportunity (EEO) framework since the passage of the Civil Rights Act in 1964. And although these efforts have produced improvements regarding fairness and diversity in the workplace, we continue to disagree about how well we're doing, and in the case of affirmative action, about "when enough is enough."

Furthermore, with the historic election of a partial African-American as President of the United States, and the near election of a female Vice-President or President, the timing seems appropriate for a new review of our progress and what we should do next regarding EEO and Affirmative Action.

Since much of the disagreement about where we are and where to go seems to result from confusion about the basic nature of equal employment opportunity and affirmative action (Fryer and Loury, 2005), the purpose of this paper is to develop a more precise model of the various EEO concepts, using the level playing field concept as a foundation. Overviews of EEO and Affirmative Action are presented first, followed by the development of a general level playing field model. This general model is then applied to Equal Employment Opportunity and Affirmative Action, and provides a basis for a more balanced analysis of the future of EEO and Affirmative Action.

\section{EQUAL EMPLOYMENT OPPORTUNITY ESSENTIALS}

The purpose of Title VII of the Civil Rights Act of 1964 (CRA) was to eliminate all of the workplace barriers that result in discrimination on the basis of race, color, sex, religion, and national origin. Age was added as a "protected class" in 1967 by the Age Discrimination in Employment Act (ADEA), and in 1990, disability was included by the Americans with Disabilities Act (ADA). Key concepts are:

- $\quad$ Organizations covered: Employers with 15 or more employees.

- $\quad$ Scope of employment actions: Discrimination is prohibited not just in recruitment and selection, but in other areas such as compensation, benefits, performance appraisal, training, promotions.

- $\quad$ Protected Classes: This phrase sometimes causes erroneous perceptions, e.g., that black is the "protected class," or that female is the "protected class." In truth, race and color (including whites) is the protected class, and sex (including males) is the protected class. All religions (including atheists) and national origins are protected classes. Regarding age, however, the protected class status extends only to those over 40 years of age.

- Disparate Impact (indirect) and Disparate Treatment (direct): Direct discrimination occurs when the protected class membership is the basis for discrimination, e.g., a black applicant is not hired because of his race. Indirect discrimination occurs when a seemingly neutral systemic feature has a roundabout impact on a protected class, e.g., a height requirement indirectly discriminates against women and Asians. 
- $\quad$ Bona Fide Occupational Qualification (BFOQ) and Business Necessity: Discrimination against a protected class may be legal if the protected class characteristic is a necessary requirement for success on the particular job, e.g., hiring only Chinese employees for the China exhibit at the World's Fair.

- $\quad$ Reasonable Accommodation and Undue Hardship: An organization is expected to exert some effort to adjust workplace conditions for the benefit of members of protected classes, as long as the adjustments are not too costly, e.g., providing women mechanics with wrenches with narrower handles to accommodate smaller hands.

\section{AFFIRMATIVE ACTION ESSENTIALS}

After the passage of the Civil Rights Act, instead of being able to simply move the civil rights "pendulum" directly from discrimination to equal employment opportunity (Figure 1), we discovered that, temporarily, some special help would have to be provided for those groups against whom the Nation had unfairly discriminated. As President Lyndon Johnson said in 1965:

"You do not wipe away the scars of centuries by saying: 'now, you are free to go where you want, do as you desire, and choose the leaders you please.' You do not take a man who for years has been hobbled by chains, liberate him, bring him to the starting line of a race, saying, 'you are free to compete with all the others,' and still justly believe you have been completely fair..."

Figure 1

Civil Rights Pendulum

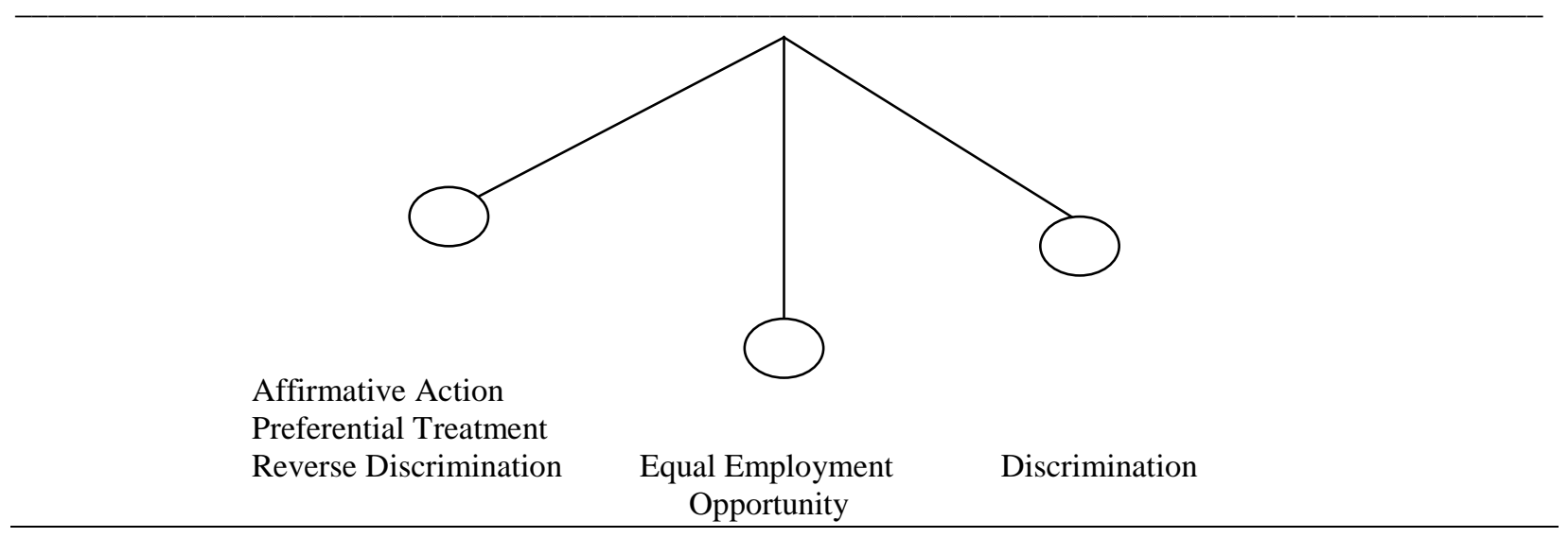

Therefore, the simple purpose of affirmative action is to provide special support, i.e. preferential treatment, to those groups within protected classes who have been, on purpose, "hobbled by chains," so that some day fairness will be present when they "come to the starting line of the race," and the pendulum (Figure 1) can move to the center position of equal employment opportunity. Affirmative Action is "payback" to those against whom society has treated unfairly. Specifically:

- Who Has Been Significantly Hobbled, By Society, On Purpose? Since 1964, there has been confusion about who the beneficiaries of preferential treatment should be, and thus the broad phrase "women and minorities" seems to have defined the targeted groups. In truth, blacks, women, Hispanics, and Native Americans are the only groups within the protected classes who have been so egregiously discriminated against that preferential treatment, contrary to the "colorblind" mandate of the Civil Rights Act, is clearly appropriate. 
- What Kinds of Chains Have Been Used Relevant to an Employment Setting? Three basic types of "chains" have caused unfairness at the employment "starting line:" insufficient education, lack of managerial work experience, and low esteem. Historically, blacks, women, Hispanics, and Native Americans were denied sufficient educational opportunities (segregated schools and discriminatory admission policies). As a result of discriminatory hiring, glass ceilings, and glass walls, previous work experience was insufficient to get new jobs or promotions. And as a result of stereotypes, restricted public accommodations, hatred, and an absence of role models, ambition, self-confidence, and a winner attitude was often missing. Selfconfidence is a critical competitive tool.

- What Types of Special Support (Preferential Treatment) Have Been Provided? In an employment setting, goals (but technically not quotas) have been developed as a basis for hiring and promoting members of disadvantaged groups. Special mentors have also been provided. And also, for example, companies near American Indian reservations can discriminate in favor of American Indians. In broader society, Native Americans can legally operate gambling casinos. Women, blacks, and American Indians have received special consideration regarding admission into institutions of higher learning. Cultural centers exist specifically for women, blacks, and Native Americans. We have women's studies programs, but not men's programs. And Black History Month, but not White History Month. In many parts of the U.S., bilingualism, Spanish and English, is the rule. In general, affirmative action by companies is aimed at eliminating the work experience chains, while societal affirmative action attempts to reduce the education and esteem chains.

- The Limits of Affirmative Action? Since affirmative action is in fact, discrimination against the majority, and against the mandate of the Civil Rights Act, the Courts have treated it cautiously. Affirmative action was intended only as a temporary measure, and was not intended to be too overpowering against the majority. In United Steelworkers of America vs Weber (1969), for example, a moderately biased (in favor of blacks) seniority plan was allowed for admission in to a company training program because it was only a temporary plan to break down old patterns of discrimination. But in Memphis Firefighters vs Stotts (1984), a layoff plan that provided biased protection to less-senior blacks was disallowed, even though the result was the loss of gains made under previous affirmative action plans. When layoffs are the issue, affirmative action cannot override seniority. Regarding the use of affirmative action in admissions in higher education, the Courts have walked a tightrope in an attempt to disallow outright quotas, but to allow disadvantaged group status to be included as one of the legitimate criteria for admissions. University of California vs Bakke (1978), State of Texas vs Hopwood (2001), University of Michigan (2003).

\section{LEVEL PLAYING FIELD: A BROAD PERSPECTIVE}

As suggested by President Johnson, protected group members face an unlevel playing field regarding employment, and thus affirmative action was necessary as an equitable solution. However, a literature search for level playing field uncovered a surprisingly more ubiquitous concept. A sampling of the articles appear in Table 1, arranged according to what seems to be the five basic competitive contexts in which level playing field is relevant: business, athletics, politics, workplace, and society. The desire for a level playing field appears to be universal.

"It's the one piece of consulting advice that seems to cross every professional field. From politics to economics, from technology to education, consultants agree: The fairest, best way to play any competitive game is on a level playing field" (FastCompany, 1998). And in a recent study of 1.4 million articles and reports from 10,000 sources worldwide, level playing field was found to be the fourth leading cliché used in a seven-month period during 2006 (Bakkum, 2006).

After sifting through the comments and articles that utilize the idea of a level playing field, it becomes possible to craft a more precise definition of the phrase. 
Table 1

Level Playing Field Competitive Contexts

\section{Business}

* Let's Have a Level Playing Field, Not Even Harley-Davidson Can Penetrate China's Market (Manufacturing and Technology News, 2006)

* A Level Playing Field for Forestry In the U. K. (Forestry and Timber Association, 2003)

* Coalition For a Level Playing Field for Automotive Wholesalers (AWANE, 2006)

Athletics

* Tour de France...Level the Playing Field With Cheating, Doping, Lying (Stein, 2006)

* American Society of Golf Course Architects calls for "level playing field" when raters evaluate golf courses for for publications (Cybergolf, 2006)

*More Level Playing Field Bitter Pill for Yankee Fans to Swallow (Louderback, 2007)

\section{Politics}

* Level Playing Field a Must in Gambia Elections (Darbo, 2006)

* I've Heard that Song Before: A Level Playing Field between Palestinians and Muslims (Ventura, 2006)

*In Campaign Finance, One Party's 'Level Playing Field' Is Another's Shaky Ground (Dewar, 1997)

\section{Workplace}

*Office relationships develop that unfairly alter the playing field (Sulkowicz, 2007)

*Workers, unions need a level playing field (MacKenzie, 2008)

*AFSCME Seeks to Level Playing Field for Physicians (Weinmann, 2008)

\section{Society}

* That All May Read...A Level Playing Field for Blind Canadians (CN Institute for the Blind, 2006)

* Involving Men in Creating a Level Playing Field for Women (World Food Programme, 2006)

*A Level Playing Field for Cities (Glaeser, 2008)

\section{What it was, was football (Andy Griffith, 1953)}

"The term 'level playing field' has become common in modern English, to refer to fair competition, particularly in the United States of America. It is a reference to a football field, where neither side has the advantage of running downhill against opponents who are handicapped by having to run uphill" (Pinto-Duschinsky, 1997). The basic solutions to this "unlevel" field would be to (1) landscape the field so that it is completely flat, (2) use a coin-toss procedure that gives the winner the choice of starting on offense or defense, and the loser the choice of field position, and (3) have the teams switch ends of the field each Quarter. The third option would have the added advantage of neutralizing other "unlevel" field-related factors such as wind, bright sun, and location of fan noise.......assuming, of course, that the wind, sun, and fans cooperate by not moving.

Table 2

Football Level Playing Fields

\begin{tabular}{|c|c|c|}
\hline $\begin{array}{l}\text { LEVEL PLAYING } \\
\text { FIELD DOMAINS }\end{array}$ & POTENTIALLY UNLEVEL FIELDS & TYPICAL LEVELING ADJUSTMENTS \\
\hline Arena of Competition & Playing field surface is irregular & Teams switch ends each quarter \\
\hline $\begin{array}{l}\text { Tools Used During } \\
\text { Competition }\end{array}$ & $\begin{array}{l}\text { Selection of a football design and material that } \\
\text { favors one team's quarterback }\end{array}$ & $\begin{array}{l}\text { Both teams use the same NCAA approved } \\
\text { football }\end{array}$ \\
\hline $\begin{array}{l}\text { Competitor Behavior } \\
\text { During Competition }\end{array}$ & $\begin{array}{l}\text { Defensive player tackles a quarterback after he } \\
\text { has thrown a forward pass }\end{array}$ & $\begin{array}{l}\text { Penalty against the defense of } 15 \text { yards and an } \\
\text { automatic first down for the offense }\end{array}$ \\
\hline $\begin{array}{l}\text { Admission To } \\
\text { Competition }\end{array}$ & Difficulty finding teams to play & $\begin{array}{l}\text { Membership in a conference guarantees a } \\
\text { schedule of opponents }\end{array}$ \\
\hline $\begin{array}{l}\text { Qualifications of } \\
\text { Competitors }\end{array}$ & $\begin{array}{l}\text { Large university football programs have } \\
\text { greater resources than small college programs }\end{array}$ & $\begin{array}{l}\text { Football teams arranged in Divisions based on } \\
\text { size: Large schools-Division I, Smaller } \\
\text { schools-Division II, Small schools-NAIA }\end{array}$ \\
\hline
\end{tabular}


But if the purpose of a level playing field is to remove any "unfair" advantages that one competitor may have over another, then the definition of level playing field must be expanded to include not just the physical field, but a wider variety of potentially unfair (unleveling) factors. When reflecting upon the variety of level playing field situations identified in Table 1, and when considering the nature of football games, programs, and conferences, the taxonomy that appears in Table 2 seems to better capture the comprehensive picture of a level playing field regarding football competition. Based on people's perceptions, an "unlevel field" may be present in any of five areas (domains) of competition: arena, tools, behavior, admission, and qualifications.

\section{AN EXPANDED LEVEL PLAYING FIELD DEFINITION}

Based on the expanded football example in Table 2, a broader definition of a level playing field is:

A level playing field exists when two or more people, or groups, e.g., boxers, buyers/sellers, countries in commerce, job seekers, employees for promotions, politicians for office, are competing for resources or outcomes, and none of the competitors are disadvantaged regarding the characteristics (natural or man-made) of the arena of competition, the tools used during competition, competitor behavior during competition, admission to competition, or the qualifications of the competitors. Thus, the competition is more fairly the result of only the competitors' skills.

And this broader definition of level playing field may now be used as a basis for developing a richer model of Equal Employment Opportunity and Affirmative Action. First, however, some general observations.

\section{GENERAL OBSERVATIONS ABOUT LEVEL PLAYING FIELDS}

- $\quad$ A completely level playing field is difficult to achieve. Although a wide variety of people and groups seem to be clamoring for a level playing field, many simply see a level playing field as a myth (Cloud, 2006; Rose, 1999; Bostaph, 2005), and others question whether a level playing field is even desirable (Heskett, 2005; Samuels, 2006; Williams, 2003).

In the classic sports film, Hoosiers, the basketball team from small, rural Hickory High School made it to the Indiana State Finals in Indianapolis. Regarding the arena domain, when the team saw the playing court at the site of the Finals game for the first time, Coach Dale, played by Gene Hackman, had the players measure various aspects of the court, and then announced to a puzzled group, "I think you'll find that this court is the exact same size as the one back home! But while his message to the team was that this is $a$ level playing field, there was no way that he could change the sheer size of the venue compared with Hickory High's gym. Nor could he reduce the level of hubbub in urban Indianapolis. Although Coach

Dale found a way to neutralize these extra arena characteristics, they still represented an unlevel playing field for Hickory High. Home court advantages are difficult to eliminate. Also, when this real-life based championship game occurred, Indiana high school basketball was not organized into divisions, so it was still possible for the smallest high school to be matched against the largest high school in the Finals game. Although Hickory won the championship, Indiana nonetheless reorganized its high school basketball into divisions in order to get a more level playing field regarding the qualifications domain.

- $\quad$ If achieved, a level playing field is difficult to sustain. Another complication in achieving a level playing field is that much of human behavior is aimed at finding an unlevel field and exploiting it! The essence of business is finding a competitive advantage (an unlevel playing field) and keeping it as long as possible (perhaps with a patent?). Oil-rich nations are certainly in no hurry to share their oil reserves, except at a price which reflects all that the market will bear. In the workplace, we tend to seek employment in organizations where our particular abilities allow us to compete favorably with co-workers for pay increases. And star athletes are not eager to publicize their training secrets. While there are always those who are complaining about not having a level field, there are also an equally large number who are doing their best to secure the advantages of an unlevel field. 
- $\quad$ Leveling mechanisms are either natural or man-made. Natural mechanisms, e.g., wind, sea, human nature, work more slowly and over a longer time period, but are essentially low-maintenance regarding financial expenditures. Man-made mechanisms, e.g., rules, laws, tariffs, may work quickly, but are relatively highmaintenance regarding financial expenditures and effort to sustain. A natural mechanism is in place for ensuring, over the long run, that a level playing field will exist: ecology and survival of the fittest. The field of ecology is about how organisms interact with, and adapt to, their environment. Animals, people, organizations, and countries who face a changing environment (or an unlevel playing field), and cannot find a way to successfully adapt will not survive. The competitors who do remain will have developed the skills, tools, and behaviors which in effect level the playing field.

For example, in the medical field, the strength of the emerging Health Maintenance Organizations (HMO's) of the 1970's and 80's seemed to create an unlevel playing field for physicians who wanted to remain in private practice. But they rose to the occasion by creating physician cooperatives called Preferred Provider Organizations (PPO's), and the field was once again relatively level. An example of a natural adjustment to an unlevel playing field. Of course, the problems inherent in HMO's also contributed to the leveling.

The United States' energy requirements make us significantly dependent on global sources of oil. In other words, with respect to oil, the world in not a level playing field, i.e., some countries have more oil than others. And clearly, one of the results of this oil concentration, and dependency, is the continuous war in the Middle East. Partially, at least, the war in Iraq is a (short run) attempt to level the oil playing field. For the long run, however, the proper ecological adjustment for the United States is to develop alternative sources of energy. It's exciting to contemplate the nature of the global playing field without such a dependency on fossil fuels.

Ownership of beach property represents another example of an unlevel playing field. Owners of oceanfront homes have to contend with the ocean tides and waves eroding their "yards," while property owners elsewhere do not have that problem. In many areas, the leveling adjustments have been for taxpayers to fund beach replenishment projects, and for overall homeowner insurance premiums to contain a portion to subsidize beach property insurance premiums. Yet clearly these are only temporarily-successful adjustment mechanisms, for what scientists are predicting in the long term, is that the oceans are inevitably going to rise, far beyond beach replenishment and subsidy capabilities.

\section{AN EXPANDED EEO/AA LEVEL PLAYING FIELD}

In the workplace, employees compete with each other for pay, promotions, status, security, etc. The employing organization, as the owner of the "field," establishes rules, policies, and procedures that determine the nature of employee competition, including who is allowed to enter the organization. Various externally imposed restrictions via laws and culture also work to shape the nature of employee competition.

The idea of a level playing field is usually the cornerstone of an explanation for the necessity of workplace affirmative action. But in actuality, when utilizing the domains concept, both EEO and AA are built upon the concept of a level playing field. As indicated in Table 3, EEO essentially tries to maintain neutrality with regard to protected class status. For example, when a promotion opportunity is present, EEO attempts to ensure that race is not a factor in deciding which employee gets promoted. On the other hand, the purpose of AA is to account for the fact that certain groups within a protected class, e.g., blacks, have been unjustly disadvantaged in the past, and so should receive preferential treatment (temporarily) to make up for prior injustices. For example, when a promotion opportunity is present, AA would not simply maintain colorblindness. Instead, assuming that both a black and a white employee met the minimum qualifications for the new job, AA would result in a black being awarded the promotion, even if the white were more qualified. A previous playing field tilted in favor of whites would now be tilted in favor of blacks, with the goal of a level playing field in the long run. 
Table 3

Workplace EEO and AA Level Playing Field Framework

\begin{tabular}{|l|l|l|l|}
\hline \multicolumn{1}{|c|}{$\begin{array}{c}\text { LEVEL } \\
\text { PLAYING } \\
\text { FIELD } \\
\text { DOMAINS }\end{array}$} & \multicolumn{1}{|c|}{$\begin{array}{c}\text { TYPICAL UNLEVEL } \\
\text { PLAYING FIELDS } \\
\text { (Employee vs Employee) }\end{array}$} & $\begin{array}{c}\text { TYPICAL EEO } \\
\text { LEVELING } \\
\text { ADJUSTMENTS } \\
\text { (Neutral playing field for all } \\
\text { protected groups) }\end{array}$ & $\begin{array}{c}\text { TYPICAL AFFIRMATIVE } \\
\text { ACTION ADJUSTMENTS } \\
\text { (Preferential treatment for blacks, } \\
\text { Indians, Hispanics and women) }\end{array}$ \\
\hline $\begin{array}{l}\text { Arena of } \\
\text { Competition }\end{array}$ & $\begin{array}{l}\text { less desirable office spaces, } \\
\text { management attitudes, } \\
\text { segregated restrooms, weaker } \\
\text { sales territories }\end{array}$ & $\begin{array}{l}\text { Colorblind decisions, } \\
\text { penalties for errors }\end{array}$ & Nothing \\
\hline $\begin{array}{l}\text { Tools Used During } \\
\text { Competition }\end{array}$ & $\begin{array}{l}\text { limited access to training } \\
\text { opportunities, mentors, } \\
\text { development opportunities }\end{array}$ & $\begin{array}{l}\text { Colorblind decisions, } \\
\text { penalties for errors }\end{array}$ & $\begin{array}{l}\text { Special mentors, special } \\
\text { developmental positions, fast track } \\
\text { career path }\end{array}$ \\
\hline $\begin{array}{l}\text { Competitors' } \\
\text { (employees') } \\
\text { Behavior During } \\
\text { Competition }\end{array}$ & $\begin{array}{l}\text { harassment, shut out of social } \\
\text { networks, sabotage, gossip, }\end{array}$ & $\begin{array}{l}\text { Company anti-harassment } \\
\text { procedures, company social } \\
\text { events, guidelines and } \\
\text { penalties for errors }\end{array}$ & Nothing \\
\hline $\begin{array}{l}\text { Admission As An } \\
\text { Employee To } \\
\text { Competition }\end{array}$ & Stereotypes, Discrimination \\
\hline $\begin{array}{l}\text { Qualifications of } \\
\text { Applicants } \\
\text { Competitors) In } \\
\text { The Labor Pool }\end{array}$ & $\begin{array}{l}\text { Colorblind decisions, } \\
\text { penalties for errors }\end{array}$ & $\begin{array}{l}\text { Advertise in minority media, hiring } \\
\text { goals for special groups, } \\
\text { differential hiring standards }\end{array}$ \\
\hline
\end{tabular}

\section{OBSERVATIONS ABOUT THE TABLE 3 LEVEL PLAYING FIELD FRAMEWORK}

- Affirmative Action is not as all-encompassing as often perceived. It is moderate preferential treatment (temporary) for only four groups of the many within the protected class designation. And then, it is focused on only two of the five domains: tools used during competition, and admission to competition.

- $\quad$ Equal Employment Opportunity provides a level playing field for all groups within the protected classes of gender, race and color, religion, national origin, age, and disability.

- Affirmative Action essentially focuses on acquiring special group members, and providing development tools in order to enhance their qualifications. With regard to the arena and behavior domains, Affirmative Action does not appear to provide any special treatment. For example, special group members are not allowed to come to work late, are not given better offices, etc.

- $\quad$ Eliminating Affirmative Action in organizations would have no effect on Equal Employment Opportunity. It would simply eliminate preferential treatment, and from Figure 1, allow the pendulum to settle in the middle as defined by legislation. EEO would maintain a level playing field without the need for AA.

- An employer cannot affect the qualifications of applicants (competitors) in the labor pool. Societal affirmative action is necessary for a level playing field. Preferential admissions procedures for higher education. Public transportation to allow minorities (and majorities as well) easier access to work. Fair housing and equal public accommodations rules to enhance esteem.

\section{FINAL THOUGHTS}

The simple purpose of this paper was to use the concept of level playing field to present a more refined description of EEO and AA. Hopefully, it will provide a clearer picture of what EEO/AA is and is not, and thus lead 
to a more reasoned conversation about the future of EEO/AA. Although a thorough analysis is beyond the scope of this paper, the following hypotheses provide the basis for further research:

- Given dramatically heterogeneous workplaces, the constantly changing cultural and environmental conditions, and the great diversity of the workforce, it is doubtful that a completely level playing field in the workplace is a likely outcome.

- Given the progress of Blacks and Women regarding qualifications, and thus a level playing field, it is time that affirmative action regarding those two groups be discontinued, particularly in the admissions domain. For Hispanics and Native Americans, progress does not seem to support discontinuing affirmative action in either the admissions or tools domains.

- Given human nature, and the increase in the number of annual EEO cases filed, it is unlikely that any of the EEO legislation can be discontinued. A level playing field appears sustainable only with vigorous attention to Civil Rights Title VII, ADA, and ADEA.

\section{REFERENCES}

1. _ (1998). Are These Consultants Really on the Level? FastCompany, February, 40.

2. . (2004). Let's Have A Level Playing Field, Not Even Harley-Davidson Can Penetrate China's Market. Manufacturing and Technology News, April 2.

3. _ _ (2006). Chinese Traders Should Have Level Playing Field. China View, May 25. www.chinaview.cn

4. - (2007). Involving Men in creating a level playing field for women. World Food Programme. March, www.wfp.org

5. American Society of Golf Course Architects. (2006). A Level Playing Field When Raters Evaluate Golf Courses for Publications. Cybergolf, www.cybergolf.com/news/

6. Automotive Wholesalers Association of New England. (2006) Coalition For a Level Playing Field. www.awane.com

7. Bakkum, Beth. (2006). At the End of the Day, Cliches Still Rule the Roost. New York: Factiva, from Dow Jones.

8. $\quad$ Bostaph, Sam. (2006). The Myth of the Level Playing Field. Freedom Daily, May 11.

9. Cahn, Steven M. (Ed.) (2002). The Affirmative Action Debate. New York: Routledge.

10. Canadian National Institute for the Blind. (2006). That All May Read.....A Level Playing Field for Blind Canadians. www.cnib.ca

11. Cloud, Dave. (2006). The Myth of the Level Playing Field. www.townhall.com

12. Crosby, Faye J. (2004). Affirmative Action Is Dead: Long Live Affirmative Action. New Haven: Yale University Press.

13. Darbo, Ousainou. (2006). Level Playing Field a Must for Gambia Elections. The Gambia Journal, May 25 .

14. Dewar, Helen, and Gugliotta, Guy. (1997). In Campaign Finance, One Party's 'Level Playing Field' Is Another's Shaky Ground. Washington Post, April 7, A06.

15. Forestry and Timber Association. (2003). A Level Playing Field For Forestry. www.forestryandtimber.org

16. Freidman, Thomas L. (2005). The World is Flat. New York: Farrar, Straus, and Giroux.

17. Fryer, Roland., and Loury, Glenn C. 2005. Affirmative Action and Its Mythology. Journal of Economic Perspectives, 19:3, Summer, 1.

18. Glaeser, Edward L. 2008. A level playing field for cities. The Boston Globe, February 29

19. Griffith, Andy. 1953. What It Was, Was Football. Comedy monologue that launched his career.

20. Heskett, Jim. (2005). Summing Up: Is a "Level Playing Field" a Good Thing? Harvard Business School Working Knowledge, June 27.

21. Louderback, Jeff. (2007). More Level Playing Field Bitter Pill for Yankee Fans to Swallow. Blogcritics Magazine, www.blogcritics.org 
22. MacKenzie, Mark. (2008) Workers, unions need level playing field. New Hampshire Business Review, August 1.

23. Pinto-Duschinsky, Michael. (1997). Level Playing Field, Fairness. www.aceproject.org

24. Rose, Nelson. (1999). The Myth of the Level Playing Field. www.gamblingandthelaw.com

25. Rubio, Philip F. (2001). A History Of Affirmative Action. Jackson: The University Press of Mississippi.

26. Rubio, Philip F. 2001. A History of Affirmative Action. Jackson: University Press of Mississippi.

27. Samuels, Marilyn. (2006). Unfair Advantage or level playing field? University of Calgary OnCampus

Weekly, February 3.

28. Skrentny, John David. (Ed.) (2001). Color Lines. Chicago: The University of Chicago Press.

29. Sowell, Thomas. (2004). Affirmative Action Around The World. New Haven: Yale University Press.

30. Stein, Joel. (2006). Level the Playing Field with Cheating, Doping, Lying. Fayetteville Observer, July 17, 9A.

31. Sulkowicz, Kerry. (2007). In Cupid's Cubicle. Business Week, February 26, 18.

32. Ventura, Sal. (2006). I've Heard that Song Before: A Level Playing Field between Palestinians and Muslims. www.myopera.com

33. Weinmann, Robert. (2008). AFCSME Seeks to Level Playing Field for Physicians. Healthcare Journal of Northern California, Fall.

34. Williams, Walter. (2003). The Level Playing Field Act. Capitalism Magazine, September 18. 
NOTES 